\title{
Administrative Law Judges in Fair Housing Enforcement: Attitudes, Case Facts, and Political Control*
}

\author{
Nicholas R. Seabrook, University of North Florida \\ Eric M. Wilk, Georgia Gwinnett College \\ Charles M. Lamb, University at Buffalo SUNY
}

Objective. This study investigates the effect of attitudes, case facts, and political control on the fair housing decisions made by administrative law judges (ALJs) at the Department of Housing and Urban Development (HUD). Methods. Based on data obtained from HUD under a Freedom of Information Act request, we use Probit regression to model the outcomes of every housing discrimination case decided by the entire population of ALJs between 1989 and 2003. Results. We discover significant variation in the likelihood of a pro-complainant outcome and the amount of actual damages awarded in fair housing disputes. Conclusion. The attitudinal model of judicial decision making appears to apply to ALJ behavior in housing discrimination cases. At the same time, case facts, bureaucratic oversight, and other legal factors constrain ALJs.

Researchers have long been interested in why judges decide cases the way they do (Segal and Spaeth, 2002), but the vast majority of these studies have focused on the decisions of judges acting in a purely judicial capacity in cases before the federal and state courts, rather than in a quasi-bureaucratic capacity (Baum, 2011). This article draws on the literature exploring the influence of attitudes and case facts on judicial decision making in order to test those findings in a quite different context from that in which they are usually investigated - the decisions of federal administrative law judges (ALJs). We test both attitudinal and fact-based determinants, along with any bureaucratic effects, of judicial behavior in ALJ decisions in housing discrimination cases at the U.S. Department of Housing and Urban Development (HUD).

Although ALJs are similar to other federal judges in their role as adjudicators, they differ significantly from other federal judges in terms of their method of selection. Although Article III judges are political appointees who

* Direct correspondence to Nicholas R. Seabrook, Department of Political Science \& Public Administration, University of North Florida, 1 UNF Dr., Jacksonville, FL 32224; n.seabrook@unf.edu. A previous version of this article was presented at the 2009 meeting of the Northeastern Political Science Association in Philadelphia, PA. We are grateful to James Coleman Battista, Christina L. Boyd, Donald B. Rosenthal, and the anonymous reviewers for their valuable comments. The authors will share all data and coding for replication purposes. 
are nominated by the president and confirmed by the Senate, often along partisan and ideological lines, ALJs are employees of the federal bureaucracy appointed through a merit system based on competitive examinations. Yet like Article III judges, ALJs enjoy significant judicial independence, and are insulated substantially from the political branches of government, and this allows them considerable latitude to decide cases based on personal attitudinal considerations (Taratoot and Howard, 2011). ${ }^{1}$

This study contributes to two areas of scholarship: the fair housing literature, by analyzing the determinants of ALJ decision making in housing discrimination cases, and the judicial politics literature, by investigating the potential for merit-based hiring and bureaucratic oversight to mitigate the effects of attitudes on the judicial behavior of ALJs. Specifically, we explore the behavior of all eight ALJs who decided every Fair Housing Act case at HUD between 1989 and 2003. Data on the attitudinal characteristics of these eight HUD ALJs are combined with a large, unique dataset gained through a Freedom of Information Act request (U.S. Department of Housing and Urban Development, 2005), containing a rich array of information on the case characteristics for all ALJ decisions at HUD during this period. Our purpose is to determine if ALJ attitudes, case facts, and political control are related to their decisions for or against complainants and the damages awarded in housing discrimination disputes.

\section{HUD and Federal Fair Housing Enforcement}

HUD and its ALJs are responsible for enforcing several federal statutes requiring equal housing opportunity. The most important of these are the Fair Housing Act of 1968 (Title VIII of the Civil Rights Act of 1968) and the Fair Housing Amendments Act of 1988 (also known as Title VIII). Taken together, these two laws prohibit discrimination on grounds of race, color, religion, sex, national origin, disability, or families with children by refusing to rent or sell housing after a bona fide offer is made; in the terms, conditions, or privileges in the rental or sale of housing; in loans for purchasing, constructing, improving, or repairing housing; and by denying access to or membership in a multiple-listing service or organization for real estate brokers, as well as making it illegal to advertise to rent or sell housing in a way that indicates a preference, limitation, or discrimination and falsely representing the availability of housing for rent or sale (Schwemm, 2011). During the years covered by this study, a total of eight ALJs were employed by HUD, and we focus specifically on the Title VIII cases that those eight ALJs decided over the 15-year period included in our dataset.

\footnotetext{
${ }^{1}$ ALJs are not political appointees subject to removal when a new administration takes office. They also have much greater independence from their hiring agency than other civil servants do. In many ways, then, ALJs enjoy judicial independence and tenure that is "functionally comparable" to Article III judges (Taratoot and Howard, 2011).
} 
The HUD Secretary, who is assigned the responsibility of enforcing Title VIII, delegates that task to the Assistant Secretary for Fair Housing and Equal Opportunity (FHEO). Then the critical administrative roles are played by two entities: HUD's Office of FHEO and a variety of "substantially equivalent" state and local civil rights agencies that are certified and funded under HUD's Fair Housing Assistance Program (FHAP). The FHEO-FHAP enforcement process involves three stages (Lamb and Wilk, 2010). First, both FHEO and FHAP agencies perform an intake function: they receive inquiries from persons who believe their rights have been violated, decide if those inquiries indeed indicate that Title VIII may have been breached, and file complaints in appropriate cases. Second, either FHEO or a FHAP agency conducts an investigation, determines if there is reasonable cause to believe that discrimination has occurred, and attempts to conciliate complaints where possible. The third stage is the adjudication function, at which an ALJ or a federal or state court decides if a respondent has in fact violated a fair housing law. When HUD concludes there is reasonable cause to think that Title VIII has been violated and neither the complainant nor the respondent elects to have the case tried in federal district court, the case is assigned to an ALJ.

ALJs handle cases individually rather than as members of panels. This means that ALJs hold hearings and reach decisions completely separate and apart from the investigations and conciliations conducted by HUD and the making of original reasonable-cause determinations. Attorneys from HUD's Office of General Counsel argue cases for complainants at ALJ proceedings free of charge, and the ALJ hands down a ruling after hearing the evidence and arguments from both parties to a complaint. ALJs may award compensatory and punitive damages to complainants and impose civil penalties on a finding of a Title VIII violation. Once an ALJ makes a ruling in a housing discrimination case, that ruling may be appealed directly to the U.S. Court of Appeals for the circuit within which the dispute arose, which may affirm, reverse, or modify the decision of the ALJ. Being subject to appellate review may be expected to have the effect of somewhat mitigating the influence of ideology on ALJ decision making, as is the case in the lower federal courts (Rowland and Carp, 1996). However, in practice an extremely small percentage of ALJ rulings are appealed to the Courts of Appeals. ${ }^{2}$

\section{Attitudes, Facts, and Judicial Decisions}

Two bodies of literature inform this study. One examines judicial behavior; the other addresses fair housing policy and its enforcement. Research into judicial behavior helps us understand how ALJs may behave as judges. Fair

${ }^{2}$ Of the 1,784 cases decided by HUD ALJs between 1989 and 2003, only 44 were appealed to the Courts of Appeals, and in only five of these was the ALJ decision ultimately overruled through an outright reversal. 
housing research allows us to appreciate the political, legal, and administrative context in which ALJs perform their judicial functions.

A great deal of judicial behavior research since the early 1960s has been driven by the theory that the personal attitudes and policy preferences of Supreme Court justices largely explain their voting behavior and opinions, given the facts in the cases decided (e.g., Schubert, 1965; Spaeth, 1963). In the words of Segal and Spaeth (2002:312), the attitudinal model is anchored in the notion that "the justices base their decisions on the merits on the facts of the case juxtaposed against their personal policy preferences." 3 Research on the federal Courts of Appeals (Hettinger, Lindquist, and Martinek, 2004; Songer and Haire, 1992) and on the federal district courts (Carp and Stidham, 1987) indicates that judges' attitudes affect their decisions as well, albeit to a lesser extent than those of the Supreme Court.

Beyond determining the effects of attitudes on judicial behavior, attitudinal theory often posits that judges' independence and insulation from political pressures actually permits personal policy preferences to have a potentially powerful influence on judicial outcomes (Rohde and Spaeth, 1976:72). Similarly, ALJs have a significant degree of independence and insulation from agency pressures (Taratoot and Howard, 2011). According to Schill (2007:172), the independence of ALJs is reflected in the fact that they enjoy the protections of the Administrative Procedure Act; the Office of Personnel Management, instead of their employing agency, determines their salaries; and they may be fired only for good cause, which the Merit Systems Protection Board determines. This independence suggests that ALJs may decide cases based on their attitudes and policy preferences, somewhat like federal district court judges (Taratoot and Howard, 2011).

Political science research into the influence of case facts on judicial behavior - an aspect of the legal model of judicial decision making-is less extensive in recent years than the attitudinal literature. Still, it suggests why judges decide the way they do, with the work of Kort (1966) and Segal $(1984,1986)$ leading the way. This approach attempts to determine how and what facts, or combination of facts, lead to judicial outputs for or against the parties in a case. It assumes that judges respond to certain facts as legal considerations but they interpret them in terms of their own attitudes and then behave accordingly (Segal, 1984). For instance, a litigant's race is a fact that should be irrelevant to how judges dispense with cases, yet research has long demonstrated that some judges are more likely to rule for or against the claims of African Americans than are other judges (Kort, 1966). In one article, Segal (1984) uncovers statistically significant relationships between the Supreme Court's search and seizure decisions and a number of legal variables.

\footnotetext{
${ }^{3}$ Although Segal and Spaeth (2002) insist that attitudes plus case facts explain Supreme Court justices' decisions, various scholars argue that legal doctrine, strategic behavior inside the Court, the Court's own rules, and the political environment must also be taken into account. See, for example, Bailey and Maltzman (2008); Epstein and Knight (1998).
} 
We expect, therefore, that similar legal factors in fair housing disputes, such as the type of discrimination alleged, should also affect ALJs' decisions.

Studies by political scientists that focus specifically on the behavior of ALJs are rare and of recent vintage. Taratoot (2008) explores ALJ decisions between 1991 and 2006 in more than 5,000 cases at the National Labor Relations Board. He finds that attitudes influenced ALJ decisions in these cases, with party identification "making anywhere from an 11-12\% difference in the probability of a pro-labor decision" (Taratoot, 2008:102). In another study, Taratoot and Howard (2011) conclude that ALJs are comparable to federal district court judges in the sense that ideology affects their decisions and that they, like district court judges, are subject to hierarchical control by appellate courts. Taratoot (2008:102) further suggests that "if labor law represents an area of the law as seemingly apolitical as Rowland and Carp (1996) believe, then one can only imagine how politically motivated administrative law judges would behave in more areas of law that have historically been more politically divisive." ALJs' behavior in fair housing disputes provides a good example of such a politically divisive policy context in which to test the determinants of judicial behavior. Controlling for case characteristics, we expect that ALJs with a liberal ideology should be more likely to find in favor of the complainant in fair housing disputes than ALJs with a conservative outlook.

Previous research further suggests that ALJs may also be influenced by bureaucratic pressures because they are bureaucrats subject to a certain degree of political control (Taratoot, 2008; Taratoot and Howard, 2011). Just as federal judges must work strategically within the framework of the federal court system, in which the level of ideological divergence from courts higher up the judicial hierarchy constrains the behavior of lower courts (Songer, Segal, and Cameron, 1994), ALJs also must work within the administrative framework of the bureaucracy. The ideology of an ALJ's superiors, most notably the president and his appointees in the executive branch, may similarly constrain ALJs' ability to decide cases solely based on their individual policy preferences.

\section{Fair Housing, Enforcement, and the ALJs}

Political scientists have devoted relatively little attention to housing discrimination and segregation as research priorities. Nonetheless, recent scholarly work may provide insights for the present study in terms of two key variables: enforcement outputs and monetary remedies assessed when discrimination is found to have occurred.

Regarding fair housing enforcement, Lamb and Wilk (2010) analyze favorable outcomes by HUD and state and local FHAP agencies in Title VIII complaints between 1989 and 2004. Focusing on the extent to which civil rights agencies at all three levels of government decide in favor of Title VIII complainants, they discover that federal implementation of national fair housing policy does not necessarily lead to the most favorable administrative outcomes 
for complainants. This study suggests significant institutional variation in the probability of a favorable outcome for a fair housing complainant. Here, we extend this line of research to consider how ALJs may resolve fair housing disputes differently than either HUD or state and local enforcement agencies.

Regarding compensation where discrimination is found to have taken place, Lamb and Wilk (2009) present data on the total amount of monetary relief HUD and FHAP agencies provided in Title VIII complaints closed between 1977 and 2001. They reveal a dramatic increase in the amount of monetary compensation won for housing discrimination victims during the Clinton administration, yet HUD, not state and local agencies, provided over 70 percent of that relief. Our study complements this research by analyzing the determinants of total monetary relief in cases that HUD ALJs adjudicated.

Also pertinent to our study is the research of Schill and Friedman (1999). They discover that ALJs decided for Title VIII complainants over five times as often as for respondents in cases charged by HUD between 1989 and 1998. They also find that two-thirds of all Title VIII cases were settled rather than being closed by an ALJ ruling. In addition, they found median compensatory and punitive damages to be lower where a settlement occurred than where an ALJ found a Title VIII violation (see also Schill, 2007). Our work differs from theirs in that we examine the decisions of HUD ALJs by measuring the relationship between judicial attitudes, outputs, and monetary relief.

\section{Data and Methods}

We obtained the data employed in this analysis through a Freedom of Information Act request to HUD (U.S. Department of Housing and Urban Development, 2005) and through a detailed investigation into the background and attitudinal characteristics of the ALJs employed by HUD. The dataset contains extensive information on all 1,784 Title VIII disputes adjudicated by all eight HUD ALJs between 1989 and 2003, including the type of discrimination alleged, the location of the complaint, the presiding ALJ, whether there was a hearing and/or a trial, details of the method and nature of the disposition of the dispute, and whether there was an appeal to the U.S. Courts of Appeal. The first dependent variable in the analysis is whether there was a pro-complainant adjudication, coded as 1 if the ALJ decided the case in favor of the complainant alleging discrimination in the form of a finding of liability on the part of the respondent, 0 if not. ${ }^{4}$ The second dependent variable is the total amount of monetary damages awarded in the case, including actual

\footnotetext{
${ }^{4}$ Of the cases decided by HUD ALJs during this period, $86.5 \%$ resulted in a favorable outcome for the complainant, whereas the remaining $13.5 \%$ were decided in favor of the respondent. These numbers are fairly similar to those reported by Schill (2007), whose survey of 161 Title VIII complainants and 126 respondents identified a 5:1 ratio of pro-complainant to pro-respondent ALJ decisions at HUD.
} 
damages, punitive damages, and attorney's fees. ${ }^{5}$ Because of missing data, a number of Title VIII cases had to be dropped from the analysis, yielding 1,218 usable cases for the model of the probability of a finding of liability in the case, and 1,210 usable cases for the model of the total monetary damages awarded.

The major attitudinal variable of interest in our empirical analysis is party identification, which here serves as a proxy measure for ideology as in previous studies of ALJ behavior (Taratoot, 2008; Taratoot and Howard, 2011). Party identification was determined through a confidential interview with a former HUD ALJ and through reference to campaign finance disclosure reports and voter registration records, following the procedure Taratoot (2008) used. Of the eight HUD ALJs, three were Democrats, two were Independents, two were Republicans, and the party identification of one could not be determined. We include dummy variables for Independent/undetermined and Democratic ALJs to compare them to the baseline category of Republican ALJs. Obviously, the small number of ALJs in the analysis presents some difficulties with generalizability. Still, if the data reveal patterns consistent with the previous attitudinal literature as it relates to other areas of judicial behavior, then we might suppose that the theory also helps explain the behavior of HUD ALJs.

Prior to conducting a multivariate analysis that controls for various factors, including case facts, examining the general relationship between party identification and Title VIII outcomes is useful. Figure 1 presents preliminary evidence that partisanship influences ALJs by providing simple descriptive statistics for the percentage of favorable outcomes by party affiliation. Democratic ALJs are the most likely to provide pro-complainant outcomes (46 percent favorable), whereas such outcomes are least likely to occur with Republican ALJs (38 percent favorable). Independent ALJs have a rate (45 percent favorable) similar to that of Democrats. Although revealing, these results deserve further scrutiny, and we will test them more thoroughly using more comprehensive models.

In addition to the attitudinal characteristics of the presiding ALJ, we also control for the case facts in each Title VIII dispute. The type of discrimination alleged has been shown to be a significant determinant of the probability of a favorable outcome in fair housing enforcement (Lamb and Wilk, 2010). For this reason, we include dummy variables for whether the complainant alleged racial discrimination, religious discrimination, or discrimination on the basis of family status, disability, national origin, gender, or retaliation. ${ }^{6}$ These categories are not mutually exclusive-an allegation of one type of

${ }^{5}$ The total monetary damages awarded ranged from zero to $\$ 1,166,862$, with a mean of $\$ 6,052$ and a standard deviation of $\$ 36,958$. The vast majority of this represents actual damages; the amount of punitive damages and attorney's fees awarded averaged $\$ 655$ and $\$ 391$ respectively, with maximum values of $\$ 55,000$ and $\$ 50,503$.

${ }^{6}$ Retaliation in fair housing refers to any act of harm by the owner, manager, or agent of a property against a resident or applicant in response to that resident's or applicant's attempt to exert fair housing rights. The Fair Housing Amendments Act additionally makes it unlawful to "coerce, intimidate, threaten, or interfere with any person ... on account of his having aided or encouraged any other person in the exercise or enjoyment of, any right granted or protected 
FIGURE 1

Percentage of Pro-Complainant Outcomes in Title VIII Cases Adjudicated by HUD by ALJ Party Identification, 1989-2003

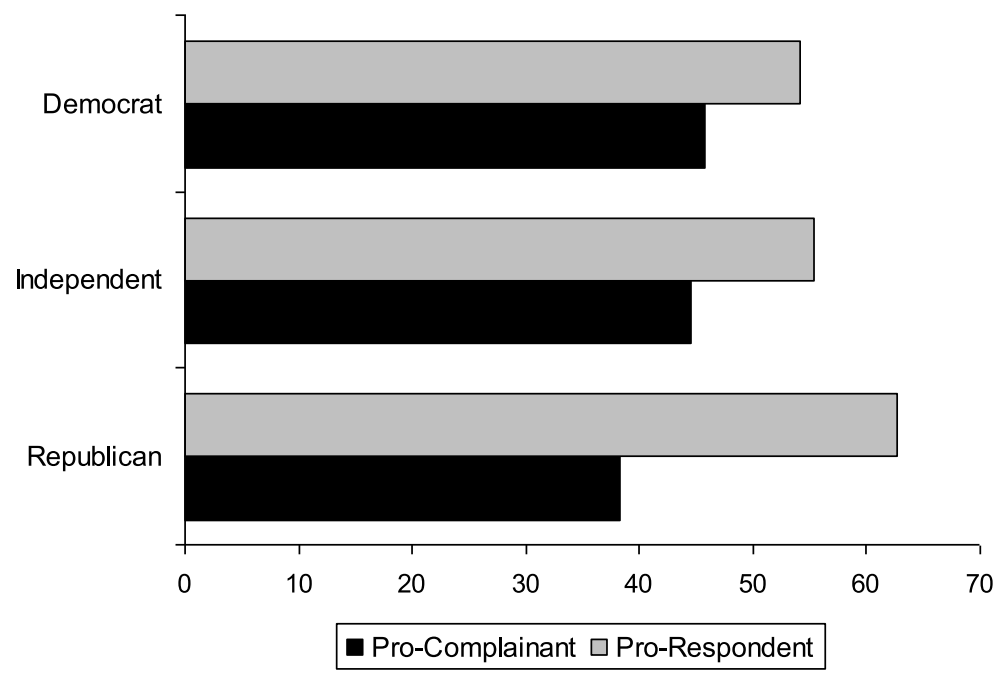

discrimination in a dispute does not preclude allegations of other types as well. However, due to the extremely small number of cases in which there is overlap, as well as the statistical implications of this, we exclude family status discrimination (the modal category) from the model, thereby treating it as the base category. ${ }^{7}$ To test for whether claiming more than one type of discrimination leads to more favorable outcomes for the complainant, we include a dummy variable for disputes in which the complainant alleged multiple types of discrimination.

Further, we include a southern control variable to test for potential differences in fair housing enforcement given the South's historical resistance to federal civil rights laws. ${ }^{8}$ We also include control variables for whether the dispute was resolved through a settlement or through a trial. Because federal fair housing procedures allow for either the complainant or the respondent

by ... this title." The use of lawsuits to counter and discourage fair housing discrimination claims has also, in certain circumstances, been held to constitute illegal retaliation (Schwemm, 2011).

${ }^{7}$ Where all categories are included, the resulting coefficients effectively capture the difference between the cases falling only into that particular category, and those in which there is overlap, thus obscuring potentially interesting differences among categories. When all categories are included in the model, none of the coefficients is statistically significant, yet significant differences among categories emerge when family status discrimination is excluded.

${ }^{8}$ The variable is operationalized in the form of a dummy variable for the 11 southern states that seceded from the Union prior to the Civil War. 
in a dispute to elect to have the matter heard by a federal district court, we include a control for cases in which one or both of the parties invoked this option in order to isolate the effects of the ALJs. Finally, to control for the potential effects of strategic behavior by the ALJs in response to bureaucratic oversight and bureaucratic pressure from political elements further up the administrative hierarchy, we also include a dummy variable for cases that were adjudicated while a Democratic president was in power, along with one for an interaction between the partisanship of the ALJ and the partisanship of the president.

\section{Results}

Table 1 presents the results of the model predicting the probability of a favorable outcome (i.e., a pro-complainant adjudication resulting in a finding or admission of liability on the part of the respondent) based on the facts of the case and the attitudinal characteristics of the ALJ. Because the dependent variable is dichotomous, we use Probit regression to estimate the models in Table 1. Model 2 then adds the interactions between ALJ party identification and presidential party so as to highlight any bureaucratic effects that might be at play. To address problems with heteroskedasticity, all models were estimated with robust standard errors clustered on the ALJ.

Table 1 indicates that the facts of a case have significant effects on the probability of a favorable outcome. The attitudinal model also seems to apply, although the small number of total ALJs and resulting lack of variation in ALJ attitudes make generalization difficult. Still, the results are consistent with the attitudinal literature and suggest that the individual characteristics of ALJs affect the decision-making process.

The results show that several types of discrimination were more likely to result in a pro-complainant outcome than the baseline category of family status discrimination, most notably discrimination on the basis of race, gender, and religion, each of which were statistically and substantively significant in Table 1. Conversely, discrimination on the basis of retaliation had a significant negative effect, whereas the coefficients for disability discrimination and discrimination based upon national origin were not significantly different from the baseline category.

These results differ markedly from those uncovered by Lamb and Wilk (2010), who investigated the determinants of pro-complainant outcomes in all Title VIII complaints that federal, state, and local enforcement agencies processed. Their research finds that an allegation of discrimination on the basis of family status had a strong positive effect on the probability of a favorable outcome, although that study does not compare the impact of these various types of discrimination to a baseline category. Here, our results suggest either that the types of cases that come before ALJs are very different from those being dealt with in other venues, or ALJs are using different decisional criteria from 
TABLE 1

Determinants of Pro-Complainant Outcomes in Title VIII Cases. Adjudicated by HUD ALJs, 1989-2003

\begin{tabular}{|c|c|c|}
\hline & Model 1 & Model 2 \\
\hline Racial discrimination & 0.440* & $\begin{array}{c}0.518^{* *} \\
0.277)\end{array}$ \\
\hline Gender discrimination & $\begin{array}{l}1.021^{* * *} \\
(0.199)\end{array}$ & $\begin{array}{l}1.072^{* * *} \\
(0.195)\end{array}$ \\
\hline Disability discrimination & $\begin{array}{c}0.268 \\
(0.329)\end{array}$ & $\begin{array}{c}0.295 \\
(0.324)\end{array}$ \\
\hline National origin discrimination & $\begin{array}{r}-0.086 \\
(0.718)\end{array}$ & $\begin{array}{r}-0.079 \\
(0.730)\end{array}$ \\
\hline Religious discrimination & $\begin{array}{l}0.418^{* * *} \\
(0.161)\end{array}$ & $\begin{array}{c}0.499^{* *} \\
(0.198)\end{array}$ \\
\hline Retaliation discrimination & $\begin{array}{c}-0.925^{* *} \\
(0.446)\end{array}$ & $\begin{array}{c}-0.873^{* *} \\
(0.429)\end{array}$ \\
\hline Multiple discrimination & $\begin{array}{c}0.048 \\
(0.558)\end{array}$ & $\begin{array}{c}0.007 \\
(0.553)\end{array}$ \\
\hline District court & $\begin{array}{c}-2.230^{* * * *} \\
(0.464)\end{array}$ & $\begin{array}{c}-2.205^{* * *} \\
(0.462)\end{array}$ \\
\hline Trial & $\begin{array}{l}2.278^{* * * *} \\
(0.453)\end{array}$ & $\begin{array}{l}2.329^{* * * *} \\
(0.436)\end{array}$ \\
\hline Settlement & $\begin{array}{l}3.652^{* * *} \\
(0.506)\end{array}$ & $\begin{array}{l}3.706^{* * * *} \\
(0.486)\end{array}$ \\
\hline South & $\begin{array}{c}0.246 \\
(0.393)\end{array}$ & $\begin{array}{c}0.229 \\
(0.365)\end{array}$ \\
\hline Democratic president & $\begin{array}{c}0.051 \\
(0.200)\end{array}$ & $\begin{array}{l}0.528^{* *} \\
(0.231)\end{array}$ \\
\hline Independent ALJ & $\begin{array}{c}0.197 \\
(0.306)\end{array}$ & $\begin{array}{c}0.538 \\
(0.438)\end{array}$ \\
\hline Democratic ALJ & $\begin{array}{r}0.634^{*} \\
(0.447)\end{array}$ & $\begin{array}{c}0.778^{*} \\
(0.494)\end{array}$ \\
\hline Democratic ALJ $\times$ Democratic president & & $\begin{array}{c}-0.388 \\
(0.360)\end{array}$ \\
\hline Independent ALJ $\times$ Democratic president & & $\begin{array}{c}-0.741^{* * *} \\
(0.249)\end{array}$ \\
\hline Constant & $\begin{array}{c}-1.848^{* * *} \\
(0.588)\end{array}$ & $\begin{array}{c}-2.109^{* * * *} \\
(0.627)\end{array}$ \\
\hline Number of cases & 1,218 & 1,218 \\
\hline Percentage of correctly predicted & 0.975 & 0.975 \\
\hline Percentage of reduction in error & 0.942 & 0.942 \\
\hline
\end{tabular}

NOTE: Models estimated using Probit regression with robust standard errors clustered on ALJ. Dependent variable is the probability of a favorable outcome.

${ }^{*} p<0.01 ; * * p<0.05 ;{ }^{* * *} p<0.10$; one-tailed. 
other actors in fair housing enforcement. The models also suggest that a procomplainant outcome is no more likely when multiple types of discrimination are alleged, which is also in contrast with prior findings (Lamb and Wilk, 2010)?

Model 1 further illustrates that Title VIII disputes that were disposed of either through settlement or trial are significantly more likely to result in a pro-complainant outcome than those disputes resolved at an earlier stage in the process. In fact, these two variables are the two largest determinants of the outcome of the dispute and explain the lion's share of the variation in the dependent variable. These findings suggest that HUD ALJs are very successful at identifying and dismissing less meritorious and perhaps frivolous claims at an earlier stage of the process as well as allowing only those in which there was a credible allegation of discrimination to proceed to the trial or settlement stage. In fact, fully 85 percent of those disputes that reach the trial stage result in a finding of liability against the respondent, whereas an even greater 98 percent of cases that were settled involved an admission of liability on the respondent's part. In the remaining cases, the charges were generally quickly dismissed. The results further show that a pro-complainant outcome was more likely when an ALJ adjudicated the case than when one or both of the parties elected to have a federal district court judge hear it.

Table 1 also uncovers attitudinal effects on the decision making of HUD ALJs. In Model 1, Democratic ALJs were more likely than Republicans, the excluded category, to find in favor of the complainant. The substantive impact of this effect is that Republican ALJs are 16 percent less likely to make a finding of liability on the part of the respondent when the complainant alleged discrimination than Democratic or Independent ALJs, holding all other independent variables constant. The $p$-value is not particularly low, but the Democratic Party variable does achieve significance at the 0.10 level for a one-tailed test. Unfortunately, the small number of total ALJs prevents strong generalizations from any party effects that this particular dataset uncovered. Still, the results are consistent with previous tests of the attitudinal theory of judicial behavior (Taratoot and Howard, 2011). The results also appear consistent with prevailing partisan attitudes on the issue of fair housing, which reveal that Democratic presidents are more likely to support a tougher and more extensive fair housing enforcement role on the part of the federal government, whereas Republican presidents have usually taken a less proactive stance on enforcing housing discrimination laws (Lamb, 2005; Lamb and Wilk, 2009). So, although the small number of total ALJs makes generalizing difficult, the results are consistent with the attitudinal theory of judicial behavior and seem to support a priori expectations.

\footnotetext{
${ }^{9}$ The coefficient for multiple discrimination is extremely sensitive to the choice of reference category for the types of discrimination alleged. Although excluding family status leads to multiple discrimination becoming statistically insignificant, different reference categories produce a statistically significant positive effect, possibly explaining this incongruence with previous research.
} 
Model 1 reveals no significant independent effect for the party of the president, but Model 2 uncovers a conditional effect of bureaucratic oversight on the behavior of Republican ALJs. Republican ALJs were significantly more likely than were Independents to rule in favor of the complainant during a Democratic administration, compared to when a Republican was president. ${ }^{10}$ Stated otherwise, Republican ALJs are more pro-complainant under a Democratic president compared to Independents, whereas the opposite is true during a Republican administration. In contrast, Democratic ALJs do not become more pro-respondent when Republicans are in the White House.

At least two explanations are possible for this finding. One is that the presence of a Democrat in the White House constrains Republican ALJs' behavior. However, the fact that Democratic ALJs do not become more prorespondent during a Republican presidency seems to counter that argument. A different possibility might stem from the overall culture of HUD. As a federal agency, one of HUD's responsibilities under Title VIII is to protect individuals from housing discrimination. This may promote an agency culture that is particularly sensitive to claims of discrimination, thereby creating a general pro-complainant environment throughout the agency. This is particularly relevant when discussing the behavior of ALJs as opposed to Article III judges, since they are appointed through a merit system by the bureaucracy that employs them. In light of these agency effects, the interaction terms may not necessarily indicate that Republican ALJs move toward the president's policy when Democrats occupy the White House. Instead, perhaps Republican ALJs are more likely to resist agency culture when their party occupies the White House. Of course, this interpretation is speculative and deserves further study. Furthermore, the results of the interactions appear to be somewhat mixed, and this could be a product of the low number of ALJs.

Table 2 displays the results for our model of the determinants of the amount of monetary damages awarded in Title VIII cases. Because the dependent variable here is continuous, we use OLS regression to estimate the models. To ease the interpretation of the results, we measure total monetary damages awarded in thousands of dollars. The results once again indicate that both case facts and attitudes are important determinants of the outcomes of fair housing disputes. Model 3 is estimated for all cases, whereas Model 4 restricts the sample to cases in which there was a finding of liability, and Model 5 includes the bureaucratic oversight interactions. Since the results of the first two models are similar, we focus our interpretation on Model 4-cases in which the respondent was held liable for discrimination, leaving it up to the ALJ to decide the sanctions to impose.

Table 2 reveals that the influences of the amount of monetary damages awarded are quite different from those that affected the probability of a favorable outcome for the complainant. Cases involving an allegation of discrimination on the basis of race, disability, religion, or national origin were each

\footnotetext{
${ }^{10}$ We thank a reviewer for emphasizing this point to us.
} 
TABLE 2

Determinants of Monetary Damages in Title VIII Cases. Adjudicated by HUD ALJs, 1989-2003

\begin{tabular}{|c|c|c|c|}
\hline & Model 3 & Model 4 & Model 5 \\
\hline Racial discrimination & $\begin{array}{l}12.152^{* *} \\
(4.965)\end{array}$ & $\begin{array}{l}28.492^{* *} \\
(11.781)\end{array}$ & $\begin{array}{l}28.564 * * \\
(11.748)\end{array}$ \\
\hline Gender discrimination & $\begin{array}{l}2.250 \\
(2.093)\end{array}$ & $\begin{array}{c}1.843 \\
(4.656)\end{array}$ & $\begin{array}{c}2.507 \\
(4.992)\end{array}$ \\
\hline Disability discrimination & $\begin{array}{l}3.956 * * * \\
(1.149)\end{array}$ & $\begin{array}{l}9.689^{* * * *} \\
(2.894)\end{array}$ & $\begin{array}{l}9.680^{* * * *} \\
(2.922)\end{array}$ \\
\hline National origin discrimination & $\begin{array}{c}5.047 \\
(4.682)\end{array}$ & $\begin{array}{c}15.044 \\
(14.187)\end{array}$ & $\begin{array}{c}14.306 \\
(14.426)\end{array}$ \\
\hline Religious discrimination & $\begin{array}{c}0.181 \\
(3.033)\end{array}$ & $\begin{array}{l}10.662^{* *} \\
(4.543)\end{array}$ & $\begin{array}{l}12.078^{* *} \\
(5.836)\end{array}$ \\
\hline Retaliation discrimination & $\begin{array}{c}8.361^{*} \\
(5.262)\end{array}$ & $\begin{array}{l}25.404^{* * * *} \\
(7.667)\end{array}$ & $\begin{array}{l}25.693^{* * * *} \\
(7.745)\end{array}$ \\
\hline Multiple discrimination & $\begin{array}{r}-6.396^{*} \\
(3.820)\end{array}$ & $\begin{array}{c}-15.106^{* *} \\
(5.750)\end{array}$ & $\begin{array}{c}-14.666^{* *} \\
(5.340)\end{array}$ \\
\hline Trial & $\begin{array}{l}30.037^{* * * *} \\
(11.305)\end{array}$ & $\begin{array}{c}20.660^{* * *} \\
(7.891)\end{array}$ & $\begin{array}{c}20.648^{* *} \\
(7.875)\end{array}$ \\
\hline Settlement & $\begin{array}{l}6.673^{* * * *} \\
(1.272)\end{array}$ & $\begin{array}{c}-11.208 \\
(16.900)\end{array}$ & $\begin{array}{c}-11.410 \\
(17.283)\end{array}$ \\
\hline South & $\begin{array}{r}-2.057^{*} \\
(1.162)\end{array}$ & $\begin{array}{c}-4.544 \\
(3.486)\end{array}$ & $\begin{array}{c}-4.429 \\
(3.370)\end{array}$ \\
\hline Democratic president & $\begin{array}{c}2.772 \\
(2.188)\end{array}$ & $\begin{array}{r}5.635^{*} \\
(3.644)\end{array}$ & $\begin{array}{l}14.410^{*} \\
(7.545)\end{array}$ \\
\hline Independent ALJ & $\begin{array}{c}-5.922^{* *} \\
(2.597)\end{array}$ & $\begin{array}{c}-15.248^{* *} \\
(7.013)\end{array}$ & $\begin{array}{c}-8.195^{* * *} \\
(1.914)\end{array}$ \\
\hline Democratic ALJ & $\begin{array}{c}-6.090^{* *} \\
(2.682)\end{array}$ & $\begin{array}{c}-16.297^{* * *} \\
(7.127)\end{array}$ & $\begin{array}{c}-9.669^{* * * *} \\
(2.866)\end{array}$ \\
\hline Democratic ALJ × Democratic president & & & $\begin{array}{r}-10.312^{*} \\
(6.573)\end{array}$ \\
\hline Independent ALJ × Democratic president & & & $\begin{array}{r}-11.828^{*} \\
(7.378)\end{array}$ \\
\hline Constant & $\begin{array}{c}0.373 \\
(1.823)\end{array}$ & $\begin{array}{c}20.336 \\
(15.831)\end{array}$ & $\begin{array}{c}14.942 \\
(13.308)\end{array}$ \\
\hline Number of cases & 1,210 & 519 & 519 \\
\hline Adjusted $R^{2}$ & 0.086 & 0.082 & 0.080 \\
\hline
\end{tabular}

NOTE: Models estimated using OLS regression with standard errors clustered on ALJ. Dependent variable is the total amount of monetary damages awarded.

${ }^{*} p<0.01 ;{ }^{* *} p<0.05 ;{ }^{* * *} p<0.10$; one-tailed.

associated with substantially larger amounts of monetary damages awarded than in cases involving family status discrimination. Allegations of racial discrimination in which the respondent was found to be liable brought on average approximately $\$ 27,000$ more in monetary damages than did family status discrimination cases, the excluded category, and had the largest effect of any type of discrimination. Racial discrimination is thus associated with 
larger damages awards to the complainant in cases adjudicated by HUD's ALJs, perhaps because it occupies a unique legal position, with protections against discrimination on the basis of race more firmly established and often considered more serious and more harmful to the fabric of society than other types of discrimination. The results also demonstrate that cases that went to trial were likely to result in significantly higher damages being awarded than cases that were either settled or resolved earlier on in the process without the need for trial or settlement. It is possible that the most serious discrimination cases make up a disproportionate share of those that reach the trial stage, as complainants in such cases should be less willing to accept a smaller settlement. For less serious cases of discrimination, both parties are more likely to prefer a quick settlement.

We also find that the attitudinal characteristics of the presiding ALJ are important determinants of the total amount of monetary damages awarded, although in a somewhat counterintuitive fashion. Although Republican ALJs were considerably less likely to rule that illegal discrimination had in fact taken place in a dispute, once discrimination had been established Republican ALJs were actually likely to award greater monetary damages to the complainant in the case than were Democratic or Independent ALJs. This is perhaps indicative of a higher threshold for a finding of liability on the part of Republican ALJs: if they require evidence of more severe discrimination in order to find for the complainant, and if more severe cases of discrimination generally produce greater awards of damages, then on average Republican ALJs should award more damages than Democratic or Independent ALJs would. Yet the relatively small explanatory power of the model overall - these attitudinal and case fact variables collectively explain only 10 percent of the variation in monetary damages awarded-cautions against reading too much into these results. And again, the small number of judges and resulting low variation in party identification may help explain the counterintuitive results. Still, these results suggest some interesting differences between the determinants of monetary compensation in fair housing cases and the factors influencing the probability of a favorable outcome.

Finally, Models 4 and 5 also provide some evidence of bureaucratic control and influence over the decisions of HUD ALJs. Specifically, the presence of a Democratic president in the White House was associated with, on average, an additional \$5,600 in monetary damages awarded in cases in which the ALJ found for the complainant than when a Republican occupied the Oval Office. This effect most likely reflects the significantly different policy priorities between the Clinton administration and the George H. W. Bush and George W. Bush administrations regarding fair housing. Under the leadership of Bill Clinton and his HUD secretaries, the fair housing policy of the federal government emphasized tougher enforcement of existing fair housing laws, perhaps overcoming some of the bureaucratic inertia that had developed under successive Republican administrations that deemphasized fair housing enforcement as a policy priority (Lamb, 2005). Additionally, the interactions 
in Model 5 reveal that Republican ALJs awarded significantly greater damages under a Democratic president relative to Independent and Democratic ALJs than they did during a Republican administration, providing further evidence that political pressures constrain ALJ behavior.

\section{Discussion and Conclusion}

This study has analyzed the impact of case facts and attitudes on the decision making of HUD ALJs in housing discrimination cases arising under the Fair Housing Act of 1968 and the Fair Housing Amendments Act of 1988. The results have implications both for the fair housing literature and the judicial behavior literature.

First, our results show that the effects of the type of discrimination in decisions by HUD ALJs are very different from those that previous research has shown to impact fair housing more generally. Most notably, we find a significant negative effect for allegations of discrimination on the basis of retaliation and a significant positive effect for discrimination on the basis of race, gender, and religion, as compared to the baseline category of discrimination based on family status. We also find that cases resolved later in the adjudicatory process are more likely to be favorable to complainants than are those resolved earlier. This may suggest that ALJs are effective at identifying meritless claims and able to achieve settlements or dismissal in such instances.

In addition, we hypothesized that ALJs may decide cases based on their own policy preferences, but that the merit-based selection system in place for ALJs may mitigate the effects of attitudes on judicial behavior, as ALJs play a role that is much more like that of a bureaucrat than that of a political appointee. We must be cautious about reading too much into the results given the limited population of ALJs that we are able to study. Nevertheless, our analysis showed that even with the combination of merit-based selection and a relatively high degree of judicial independence, partisanship was still a significant factor in the judges' decision making, with Republican ALJs significantly less likely to find in favor of the complainant than were Democrats.

Perhaps some of this effect stems from the fact that fair housing is and has been a divisive political issue, with the major parties taking very different positions on the issue of federal fair housing enforcement (Lamb, 2005). The attitudinal model of judicial decision making, which has received widespread support in analyses of the decisions of Article III judges, also seems to apply to the behavior of ALJs in housing discrimination cases. These results are consistent with previous research, which has shown a significant influence of attitudinal factors on ALJ behavior in unfair labor practice cases (Taratoot, 2008; Taratoot and Howard, 2011). However, we also uncover evidence that ALJs are subject to some degree of political control: Republican ALJs were more likely to rule in favor of the complainant and award greater monetary damages under a Democratic president than they would under a 
Republican, indicating that they were either constrained by or acting strategically in response to the policy priorities of the incumbent administration. The results may also indicate agency culture effects on ALJs who are, ultimately, employees of the federal bureaucracy. ALJs, therefore, like other judges who enjoy significant judicial independence, tend to decide cases based on their own preferences but within the framework of the constraints that case facts, bureaucratic oversight, and other legal factors impose.

\section{REFERENCES}

Bailey, Michael A., and Forrest Maltzman. 2008. "Does Legal Doctrine Matter? Unpacking Law and Policy Preferences on the U.S. Supreme Court." American Political Science Review 102(3):369-84.

Baum, Lawrence. 2011. Specializing the Courts. Chicago, IL: University of Chicago Press.

Carp, Robert A., and Ronald A. Stidham. 1987. "Judges, Presidents, and Policy Choices: Exploring the Linkage." Social Science Quarterly 68(2):395-404.

Epstein, Lee, and Jack Knight. 1998. The Choices Justices Make. Washington, DC: CQ Press.

Hettinger, Virginia A., Stefanie A. Lindquist, and Wendy L. Martinek. 2004. "Comparing Attitudinal and Strategic Accounts of Dissenting Behavior on the U.S. Courts of Appeals." American Journal of Political Science 48(1):123-37.

Kort, Fred. 1966. "Quantitative Analysis of Fact-Patterns in Cases and Their Impact on Judicial Decisions." Harvard Law Review 79(8):1595-1603.

Lamb, Charles M. 2005. Housing Segregation in Suburban America since 1960: Presidential and Judicial Politics. New York: Cambridge University Press.

Lamb, Charles M., and Eric M. Wilk. 2009. "Presidents, Bureaucracy, and Housing Discrimination Policy: The Fair Housing Acts of 1968 and 1966.” Politics and Policy 37(1):127-49.

2010. "Civil Rights, Federalism, and the Administrative Process: Favorable Outcomes by Federal, State, and Local Agencies in Housing Discrimination Complaints." Public Administration Review 70(3):412-21.

Rohde, David W., and Harold J. Spaeth. 1976. Supreme Court Decision Making. San Francisco, CA: W. H. Freeman.

Rowland, C. K., and Robert A. Carp. 1996. Politics and Judgment in Federal District Courts. Lawrence, KS: University Press of Kansas.

Schill, Michael H. 2007. "Implementing the Federal Fair Housing Act: The Adjudication of Complaints." Pp. 143-76 in John Goering, ed., Fragile Rights Within Cities: Government, Housing, and Fairness. Lanham, MD: Rowman \& Littlefield.

Schill, Michael H., and Samantha Friedman. 1999. "The Fair Housing Amendments Act of 1988: The First Decade." Cityscape: A Journal of Policy Development and Research 4(3):57-78.

Schubert, Glendon. 1965. The Judicial Mind: The Attitudes and Ideologies of Supreme Court Justices, 1946-1963. Evanston, IL: Northwestern University Press.

Schwemm, Robert G. 2011. Housing Discrimination: Law and Litigation. St. Paul, MN: Thompson West. 
Segal, Jeffrey A. 1984. "Predicting Supreme Court Cases Probabilistically: The Search and Seizure Cases, 1962-1981." American Political Science Review 78(4):891-900.

1986. "Supreme Court Justices as Human Decision Makers: An Individual-Level Analysis of the Search and Seizure Cases." Journal of Politics 48(4):938-55.

Segal, Jeffrey A., and Harold J. Spaeth. 2002. The Supreme Court and the Attitudinal Model Revisited. New York: Cambridge University Press.

Songer, Donald R., and Susan Haire. 1992. "Integrating Alternative Approaches to the Study of Judicial Voting: Obscenity Cases in the U.S. Courts of Appeals." American Journal of Political Science 36(4):963-82.

Songer, Donald R., Jeffrey A. Segal, and Charles M. Cameron. 1994. "The Hierarchy of Justice: Testing a Principal-Agent Model of Supreme Court-Circuit Court Interactions." American Journal of Political Science 38(3):673-96.

Spaeth, Harold J. 1963. "An Analysis of Judicial Attitudes in the Labor Relations Decisions of the Warren Court.” Journal of Politics 25(2):290-311.

Taratoot, Cole Donovan. 2008. Administrative Law Judge Decision Making in a Political Environment, 1991-2007. Unpublished Ph.D. Dissertation, Georgia State University, Atlanta, GA.

Taratoot, Cole, and Robert M. Howard. 2011. "The Labor of Judging: Examining Administrative Law Judge Decisions." American Politics Research 39(5):832-58.

U.S. Department of Housing and Urban Development. 2005. HUD ALJ Dataset. Washington, DC: U.S. Department of Housing and Urban Development, obtained by the authors through a Freedom of Information Act request. 